\title{
Results of a new cognitive method in rats on the Morris water maze used in modeling experimental Alzheimer's disease
}

\author{
Katalin Megyeri ${ }^{1 *}$, Mihály Albert ${ }^{2}$, István Gacsályi ${ }^{1}$ \\ From $1^{\text {st }}$ International Congress on Neurobiology and Clinical Psychopharmacology and European \\ Psychiatric Association Conference on Treatment Guidance \\ Thessaloniki, Greece. 19-22 November 2009
}

\section{Background}

In Alzheimer's disease (AD) the loss of neurons in the hippocampal CA3 regions is present. In rats treated by sodium azide (NaN3) via subcutaneously implanted osmotic minipumps number of CA3 cells were decreased [1]. We developed a new method to produce AD-like dementia using single intracerebrally (ic.) injected $\mathrm{NaN} 3$ in rats.

\section{Materials and methods}

The CA3 neurons were chemically lesioned by intracerebrally administration of NaN3 in doses of 8 and $16 \mathrm{mg} / \mathrm{ml}$. To examine learning functions Morris maze was used. During acquisition trials animals had to find a black platform within $120 \mathrm{~s}$. We measured the "escape latency"(msec). Detailed histopathology of brain was performed at the termination of the study. Learning function was measured after 7 days of ic. treatment.

\section{Results}

8 and $16 \mathrm{mg} / \mathrm{ml}$ doses of NaN3 significantly decreased escape time in ic. NaN3 treated rats compared to control animals. Neuronal necrosis, shrunk neurons, neurofibrillary tangle-like structures were seen in hippocampal area, also.

\section{Conclusions}

Decreased learning capability was induced by the ic. injection of $8 \mathrm{mg} / \mathrm{ml}$ and $16 \mathrm{mg} / \mathrm{ml} \mathrm{NaN3}$ dose in rats. We proved that with the new method, acut ic. injection of NaN3 produces comparable level of dementia caused

${ }^{1}$ Department of Behavioral Pharmacology, Division of Preclinical Research, EGIS Pharmaceuticals Plc., Budapest, Hungary by 31 days infusion of NaN3 using implanted osmotic minipumps [2], and it seems to be suitable to produce dementia in rats.

\section{Acknowledgements}

We thank Éva Körmöczi and Zsuzsa Helter for contributing to the experiments.

\section{Author details}

'Department of Behavioral Pharmacology, Division of Preclinical Research, EGIS Pharmaceuticals Plc., Budapest, Hungary. ${ }^{2}$ Department of Safety Pharmacology, Division of Preclinical Research, EGIS Pharmaceuticals PIc., Budapest, Hungary.

Published: 22 April 2010

\section{References}

1. Bennett MC: Chronic in vivo sodium azide infusion induces selective and stable inhibition of cytochrome c oxidase. J Neurochem 1996, 66:2606-2611.

2. Bennett MC: Chronic sodium azide treatment impairs learning of the Morris water maze task. Behav Neural Biol 1992, 58:72-75.

\section{doi:10.1186/1744-859X-9-S1-S92}

Cite this article as: Megyeri et al:: Results of a new cognitive method in rats on the Morris water maze used in modeling experimental Alzheimer's disease. Annals of General Psychiatry 2010 9(Suppl 1):S92.

Submit your next manuscript to BioMed Central and take full advantage of:

- Convenient online submission

- Thorough peer review

- No space constraints or color figure charges

- Immediate publication on acceptance

- Inclusion in PubMled, CAS, Scopus and Google Scholar

- Research which is freely available for redistribution 